\title{
A sabbatical year in the United States: planning and preparation
}

\author{
R W TALBOT
}

Negotiating the early morning traffic wending slowly into London, I thought it a good time to consider my future: second year senior registrar in surgery, MS, two to six years to a consultant appointment. Why not take sabbatical leave and fulfil my ambition of spending a year in the USA?

In this report I have attempted to summarise the organisation required before I set off for Gatwick Airport 10 months later, in the hope that it might be of value to other potential travellers.

\section{Appointment}

The decision where to go will be guided by clinical and research interests and the availability of personal contacts. It is important to allow a month for replies to postal communications and to use the telephone as much as possible. The director of the host department will play an essential role in obtaining institutional approval, initial planning of any projects, and possibly funding, but it is essential to contact the administrator designated to foreign medical graduate programmes. With a direct telephone number for this person most problems can be solved rapidly and without weeks of delay and worry.

\section{Initial travel matters}

VISA

Visa qualifying examinations are administered by the Educational Commission for Foreign Medical Graduates (3624 Market Street, Philadelphia, Pennsylvania 19104-2685; tel 215386 5900). The educational commission's medical test no longer meets visa requirements and has been discontinued. The visa qualifying examination retains its equivalency with the current Foreign Medical Graduate Examination in the Medical Sciences provided the educational commission's English test has been passed within the previous two years.

The Foreign Medical Graduate Examination in the Medical Sciences is a two day examination in basic sciences and clinical sciences. The basic science test can be taken any time after completion of the basic science curriculum at a medical school listed in the World Directory of Medical Schools. The clinical science test can be taken within one year of completion of the full clinical curriculum. These two tests can be taken separately or together.

The Foreign Medical Graduate Examination in the Medical Sciences is required for a visa to undertake a "hands on" or clinical appointment, but no exams are necessary for research or observation appointments. Once the appointment and funding have been secured the institution in which the appointment will be held or the sponsoring institution in the United States will initiate the application for a J-1 exchange visitor visa. When the documentation has been processed the certificate of eligibility (IAP-66) will be forwarded to the "alien physician."

St George's Hospital Medical School, London

R W TALBOT, MS, FRCS, senior registrar (also visiting scientist, Mayo Clinic Foundation, Rochester, Minnesota, USA)

Correspondence to: 33 Caenwood Road, Ashtead, Surrey.
Once you have received this certificate and evidence of funding and of reemployment on return to the UK, have completed an application form for a temporary non-immigrant visa (form 156, available from most travel agents or the United States Embassy) for each member of the party, and have a passport size photograph for all applicants aged 16 and above and a British passport valid for at least six months after the date of return you can obtain the visa by post or in person from the local visa branch of the US Embassy (England and Wales: Visa Branch, US Embassy, 5 Upper Grosvenor Street, London W1A 2JB. Scotland: US Consulate General, 3 Regent Terrace, Edinburgh EH7 5BW. Northern Ireland: US Consulate General, Queens House, 14 Queen Street, Belfast BT1 6EQ).

Other members of the party will receive a J-2 dependant's visa and will not be allowed to work unless they can change their visa once in the USA on grounds of financial hardship. Ideally, if other members of the family want to work while in the USA they should obtain an appointment and visa in advance.

\section{TRAVEL GRANTS}

It is not difficult to secure an appointment, but funding by the institution will not always be available. Research grants may be available through your own institution or from other sources mostly managed by or through the Medical Research Council. Advice on funding should initially be sought from your own department.

Facilities are available to help with travelling expenses, and many of the royal colleges have their own bursaries or funds endowed by medical industries. Other funds exist and are advertised in the $B M \mathcal{F}$ and Lancet and include the King Edward's Hospital Fund for London. Many of these bursaries and research grants must be applied for 18 months or more in advance. I found the direct approach to pharmaceutical companies particularly unrewarding.

It is a good idea to save four to six weeks of annual leave for embarkation. This provides an overlap in salary to cover the initial period in the USA. It is an additional comfort having your final salary paid into your depleted UK bank account after departure.

\section{Financial matters}

TAX

A tax consultant is essential because the tax status of British subjects abroad is complex and not easily gleaned from the Inland Revenue. When a person works abroad for one to two years his salary is not subject to UK income tax provided visits home do not exceed the maximum allowed. Caution is advisable when working abroad for only one year to be certain that a full year has been completed. Taking annual leave at the end of an appointment to return home can make the salary liable to tax.

Article 20 of the tax treaty between the UK and the USA may be of benefit. It states that, "if a teacher or researcher who is a resident of one country is invited to teach or engage in research in the other country, he will be exempt from tax by the host country on income from teaching or engaging in research if he is present in that country for a period not expected to exceed 2 years. If the 2-year period is exceeded, the exemption will be lost retroactively." Some research grants specifically exclude this exemption, and many employing authorities are unaware of it.

Tax deductions on mortgage interest paid at source (MIRAS) can 
continue while you are abroad, although the Inland Revenue initially denied this. It was valuable to transfer all these problems to a tax consultant, whose fees were partially tax deductible.

\section{HEALTH INSURANCE}

Health insurance is prohibitively expensive to arrange in the UK, costing a minimum of $£ 300$ per person for one year, and it should be unnecessary. Medical institutions in the USA run staff health schemes that include all members of the family, and it is wise to confirm this in advance. These schemes provide full health coverage at very reasonable rates (we pay $\$ 40$ a month for the whole family).

It is advisable to take out travellers' insurance to cover the first few days before taking up one's appointment.

\section{HOME FINANCE}

National insurance-depending on when in the fiscal year you leave the UK and for how long it may be unnecessary to pay contributions. The Department of Health and Social Security booklet Social Security Abroad (N138), available from any local office of the DHSS, gives full details, which should be confirmed by writing to the DHSS Overseas Branch, Newcastle upon Tyne NE98 1YX.

Superannuation-When taking sabbatical leave it is important to ensure that the employer's superannuation contributions are continued by the employing authority in the UK. On return home the employee's contributions can be paid retrospectively over six months.

Family allowance-The DHSS booklet Child Benefit for People Leaving Britain (CH6), available from any local DHSS office, outlines the position for families abroad. Family allowance may still be received during an absence of one year or less, but this information is far from clear and it is worth sending an application to the DHSS Overseas Branch even if eligibility seems unlikely.

Medical indemnity organisations will not insure doctors against malpractice while they work in the USA, and if notified they will suspend membership and hold the premium in credit. Indemnity for the period before departure continues unaffected. Most academic institutions in the USA will provide this insurance for those engaged in clinical work. Some colleges and organisations have reduced subscriptions for members abroad, and many journals have distribution agents within the USA.

Banking-It is important to discuss plans with the bank, who can advise on payment of bills and transfer of money to and from the USA and make provisional plans for overdraft facilities if these are likely to be required. Money can be taken to the USA either as a bank drait in dollars or as travellers' cheques. Credit card companies will send accounts directly to the bank for payment if requested to do so or to the USA for payment against a UK bank account or in dollars. Credit cards are difficult to obtain without a "credit rating" on arrival in the USA, but the local bank can usually overcome this. There is an annual charge up to $\$ 25$ for each credit card.

Savings accounts - In most cases long term saving accounts with banks and building societies pay higher interest than accounts giving easy access. Transfer of money not required into one of these accounts or preferably into savings not taxed at source will be advantageous.

\section{Property}

Letting property is complex and fraught with pitfalls. It is essential to consult a solicitor and preferably to employ an agent, despite fees of $15-20 \%$, to manage the tenancy. If the property is nortgaged the building society or bank must be informed in advance of plans to let, and it may insist that an agent be employed. It will also want to view the tenant's references.

Service contracts should be arranged for large appliances-for example, boilers and washing machines. The owner is responsible for rates and water rates, which can be paid by direct debit. Household insurance companies reduce their liabilities when the property is let and exclude breakages, damage, and theft by tenants. The terms of existing policies should be clarified. A good agent will arrange transfer of services and telephone into the tenant's name and will arrange payment of final accounts. Post should be redirected by the Post Office, preferably to someone who will handle routine correspondence and forward important letters. The agent will provide lists of furnishings required in the house, and some time should be spent preparing the house and garden. It is worth remembering that the tenant will expect everything to be in perfect working order, and repairs that the tenant initiates will invariably be more expensive than if they had been carried out before departure.

It is inadvisable to leave items of monetary or sentimental value for use in the house. Small items can be secured in a cupboard or stored with relatives, but do not forget to confirm that they are still insured. It is difficult to decide what to take to the USA, but the voltage and cycle $(120 \mathrm{~V}, 60 \mathrm{C})$ are different and most electrical appliances are incompatible without expensive stepdown transformers for high wattage appliances. Most small appliances can be purchased cheaply and sold at "garage sales" before you return home.

\section{Travel arrangements}

Obtaining a visa has already been covered. It is advisable to have children included on both parents' passports in case separate travel home may be required.

Apex and charter flights are not available for periods exceeding six months, but discounts of up to $11 \%$ can be obtained on regular single or open return flights by shopping around, particularly by checking advertisements in travel magazines. There is a temptation to fly with cheaper carriers to New York-for example, People's Express or Virgin Atlantic Airways-and to fly on from there, but the ultimate small savings over direct flights are often far outweighed by the time taken and inconvenience. It is important to realise, especially when travelling with children, that baggage must be retrieved and cleared through immigration and customs at the first airport of landing, even if onward flights are with the same carrier.

There are advantages in buying an open return ticket, especially if you have a grant towards travel costs. Single airfares from the USA are generally higher than those bought in the UK. The open return, however, is valid for only 365 days, which is too short to allow you to work a full year and avoid tax liability on the return home. We took the risk of buying return tickets and persuaded the carrier to extend them for a few weeks at no extra cost. Nothing is lost by trying because return tickets can be traded in for their full cost price.

Excess baggage charges are lower than air freight, so if the standard baggage allowance is inadequate check these charges, and restrictions on weight and dimensions, with the carrier.

\section{Driving and accommodation}

An international driving licence is not essential but is advisable because it contains a stamped photograph. Driving licences are used as identity cards in the USA, especially for cashing cheques. For a stay of longer than one year a local driving test would be required. Membership of the Automobile Association allows you to receive reciprocal services from the American Automobile Association and is a little cheaper. As a member of the American Automobile Association, however, you can obtain a Visa card without the annual $\$ 15$ charge and free travellers' cheques, which are useful for travel within the USA.

Furnished apartments may be available, but rented houses in the USA are usually unfurnished, although they may contain kitchen appliances (that is, oven, fridge, and washing machine). Furniture can be rented separately, but it is fairly easy to furnish a house from the many garage sales and through small advertisements in local newspapers. Most large institutions have their own sales and rent newspaper through which accommodation might be arranged in advance.

The immediate neighbourhood of large city hospitals is not always safe or desirable. It is not essential to arrange accommodation in advance, but if you are determined to do so a preliminary visit, finances permitting, or, at the very least, advice from a local resident, is essential. If a liaison can be established with copatriates returning to the UK exchange of accommodation, car, and furniture en bloc might be beneficial. In larger cities the quality of public schools (state schools) may vary widely and be an important factor in determining where to live.

For families with children I strongly advise against rushing into a furnished apartment. A little time and effort spent furnishing a house will pay dividends both in home comfort and in enabling you to meet other families, which is vital for domestic harmony.

Second hand cars can be bought cheaply but may turn out to be expensive to run. A newer and more expensive car can be acquired by leasing, which has the added advantage of leaving you capital with which to furnish the house.

In short, the message is to take as much money as possible and arrange for a loan or advance in salary if necessary. In the first three weeks we spent $\$ 3800$ setting up home, which included a $\$ 1000$ returnable deposit on the house and car lease.

\section{Children}

Before leaving ensure that your children's school holds a place for them on return. A résumé of the reading level and general academic grade of the children is helpful in placing them in school, especially if they are under 6 . 
American children start school at 6-61/2, but schools will usually accept foreign children who have started school at home.

Inoculation against measles, mumps, and German measles in addition to diphtheria, pertussis and tetanus and polio may be required before admission to school, but this can be arranged on arrival.

\section{Lectures}

Prepare a couple of seminars, with slides, on any original work or investigation previously performed. In addition, slides of British cities and countryside are worth having for informal lectures to show at the children's school and to friends.

\section{Departure}

Transatlantic flying is no longer romantic, especially when you are travelling with children. Try to reserve seat numbers in advance and telephone again on the morning of departure to reinforce the request and thereby avoid the all too frequent attempts to separate families on aircraft. Motel accommodation for the first night and transport from the airport can be arranged in advance with local advice.

With advance planning a period abroad can be painless and highly recommended.

(Accepted 5 September 1985)

\section{Lesson of the Week}

\section{Painful scoliosis: a need for further investigation}

\section{J TAYLOR}

When scoliosis presents in an adult it is often painful. A painful scoliosis in a child or adolescent, particularly with night pain, often indicates the presence of an underlying osteoid osteoma, osteoblastoma, severe spondylolisthesis, or spinal tumour. Routine radiographs may fail to delineate the lesion and tomography, a CT scan, radionuclide bone scan, radiculogram, or lumbar puncture may be necessary.

I describe 10 young patients who presented with painful scoliosis and in whom special investigative techniques disclosed a serious underlying cause.

\section{Middlesex Hospital, London W1}

L J TAYLOR, FRCS, senior orthopaedic registrar

Correspondence to: Central Middlesex Hospital, London NW10.

\section{A painful scoliosis in a child or adolescent requires further investigation to exclude an underlying patho- logical cause}

\section{Case histories}

Table I gives the clinical details of all 10 patients. Two cases are described below.

Case 2-An 11 year old boy was referred to the Royal National Orthopaedic Hospital in August 1983 for a second opinion about an 11 month history of right sided lower lumbar pain of spontaneous onset. The pain was increased by sitting and caused him to wake at night. The pain was not relieved by aspirin. Examination showed a healthy child with a rigid $20^{\circ}$ left thoracolumbar scoliosis. He was able to localise his pain to the clinical site of L3, but there was no local tenderness. A plain anteroposterior radiograph suggested increased sclerosis in the right pedicle of L3 (fig 1). A technetium- $99 \mathrm{~m}$ bone scan confirmed the presence of a hot spot over the site and a tomogram clearly delineated the lesion (fig 2). One year later the pedicle and lesion were excised. Relief of pain was immediate. Histological

TABLE I-Details of individual cases

\begin{tabular}{|c|c|c|c|c|c|c|c|}
\hline Case No & $\begin{array}{c}\text { Age } \\
\text { (years) }\end{array}$ & Sex & $\begin{array}{c}\text { Duration of } \\
\text { symptoms (months) }\end{array}$ & $\begin{array}{l}\text { No of specialists } \\
\text { before diagnosis }\end{array}$ & $\begin{array}{c}\text { Curve } \\
\text { characteristics* }\end{array}$ & $\begin{array}{l}\text { Resolution } \\
\text { after treatment }\end{array}$ & Diagnosis \\
\hline $\begin{array}{l}1 \\
2\end{array}$ & $\begin{array}{l}11 \\
11\end{array}$ & $\begin{array}{l}\mathrm{F} \\
\mathrm{M}\end{array}$ & $\begin{array}{l}15 \\
11\end{array}$ & $\begin{array}{l}2 \\
2\end{array}$ & \multirow{6}{*}{ 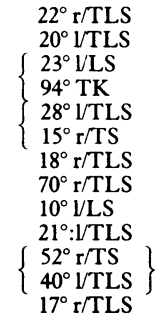 } & \multirow{6}{*}{$\left.\begin{array}{l}\text { Yes } \\
\text { Yes } \\
\text { Yes } \\
\text { No } \\
\text { Yes } \\
\text { Yes }\end{array}\right\}$} & $\begin{array}{l}\text { Osteoid osteoma } \\
\text { Osteoid osteoma }\end{array}$ \\
\hline 3 & 12 & $\mathbf{F}$ & 48 & 2 & & & Osteoid osteoma \\
\hline 4 & 12 & $M$ & 6 & 2 & & & Osteoid osteoma \\
\hline $\begin{array}{l}5 \\
6 \\
7 \\
8\end{array}$ & $\begin{array}{l}11 \\
12 \\
12 \\
14\end{array}$ & $\begin{array}{l}M \\
F \\
F \\
F\end{array}$ & $\begin{array}{l}14 \\
15 \\
11 \\
24\end{array}$ & $\begin{array}{l}2 \\
2 \\
2 \\
2\end{array}$ & & & $\begin{array}{c}\text { Osteoid osteoma } \\
\text { Spondylolisthesis (grade IV) } \\
\text { Spondylolisthesis (grade III) } \\
\text { Spondylolisthesis (grade IV) }\end{array}$ \\
\hline 9 & 19 & $M$ & 33 & 4 & & & $\begin{array}{l}\text { Astrocytoma of } \\
\text { central cord }\end{array}$ \\
\hline 10 & 19 & $\mathbf{M}$ & 18 & 1 & & & Neurilemoma \\
\hline
\end{tabular}

